\title{
Teaching Strategies that HoOK Classroom Learners
}

\author{
BY ROBERT J. FELLER AND CHRISTINE R. LOTTER
}

IT SHOULD NOT be a surprise to learn that most earth science/oceanography and other STEM (Science, Technology, Engineering, Mathematics) faculty teach classes the same way they were taught, typically using lectures (Lortie, 1975; Mazur, 2008). If the class has a weekly laboratory, this portion of the course typically consists of confirmatory exercises (i.e., the outcome is known ahead of time, just follow the directions and you should get the answer). Don't get us wrongthere is nothing particularly evil about good, fact-filled, solid lectures, nor are confirmatory lab exercises necessarily inappropriate ways to teach principles and concepts. It is just that using lecture and recipe-driven labs a majority of the time has been shown to result in poor student retention, lessthan-adequate understanding, and an aversion on the part of the students to ask questions and think for themselves (Hammer, 1995; Bransford et al., 2000; Handelsman et al., 2004).

During a typical lecture course, the instructor usually presents a highly structured sequence of information designed to illustrate certain concepts and/or principles. The exchange of information follows the path of teacherto-student-to-teacher over and over. The advent of Microsoft PowerPoint has made this lecture mode a relatively easy task, and faculty can readily modify or update their presentations quickly, even just a few minutes before a class starts. However, for the lecture part of such typical PowerPoint classroom presentations and confirmatory laboratory exercises, a body of solid educational research exists showing that there are additional and more effective ways to engage students in the learning process. We wish to bring these effective teaching strategies to the attention of all STEM faculty, especially those for whom lecturing to students is the norm.

Under the able tutelage of colleagues in the College of Education and his coauthor, RJF has learned several powerful instructional strategies that have significantly changed the way his classroom time is utilized. Until about six years ago, RJF had both lectured and instructed confirmatory laboratories since 1969 with introductory oceanography classes for majors and nonmajors, in more advanced classes in biological oceanography at the undergraduate and graduate levels, and in ecologically oriented biology courses. Having been appointed to the directorship of our university's Center for Science Education in 2003, RJF's new position entailed providing effective professionaldevelopment programs to middle and high school science teachers. In addition to providing deeper content lessons to these teachers with the assistance of colleagues in the College of Education, we promoted and actually modeled these strategies to teachers prior to their using them in practice teaching sessions and later in their own classrooms.

Here, we discuss several "tried and true" classroom and laboratory teaching strategies that promote better learning, attention, engagement, and curiosity in all kinds of students. They work just as effectively for undergraduate and graduate student classes and laboratories as they do for middle and high school students, even with nonscience majors in large classes. The strategies are designed to promote the use of studentcentered learning rather than the lecture mode of instruction (instructorcentered) that most of us experienced as undergraduates and in graduate school.

\section{ELICITING STUDENT MISCONCEPTIONS}

One of the first steps to effective teaching is eliciting your students' misconceptions and prior knowledge (Ausubel, 1960; Posner et al., 1982). Student response systems (clickers) are one way to determine your students' incoming misconceptions on a topic as well as to assess their understanding of concepts after you teach them (Feller, 2008; Smith et al., 
2008). As students enter your classroom, you can display a well-designed multiplechoice question on a PowerPoint slide that has distracters that embed common misconceptions (Feller, 2007) surrounding the topic as well as the one correct answer. Students are asked to think about the question and select an answer on their individually assigned clickers. As students submit their answers, the responses are tallied on the screen for all to see. Rich discussions typically ensue as you probe the origin of student misconceptions, allowing you to address them before moving on to higher-level thinking about the topic. Misconceptions really prevent effective learning!

You can combine the use of clickers with the Think-Pair-Share strategy (Kagan, 1994). If you have ever asked a question in class and then had all the students just look at you with blank stares, then this is the strategy for you. After students think about the topic for a minute by themselves and write down or select their initial answers, they then turn to a partner sitting next to them and discuss the reasons for their selections. After a minute or two of partner sharing, the instructor can call on students to share their reasoning for both the correct answer and for common misconceptions with the entire class. This strategy helps students gain confidence in their answers and thus can lead to a rich classroom discussion about the topic under study that is not dominated solely by the instructor. This strategy also works well in a laboratory setting.

\section{INQUIRY}

The National Science Education

Standards (NSES) separate inquiry into full and partial approaches (NRC, 2000).
According to the NSES, full inquiries have students create their own "scientifically oriented questions," "give priority to evidence in responding to questions," "formulate explanations from evidence," "connect explanations to scientific knowledge," and "communicate and justify explanations," while partial inquiries rely more on teacher direction in one or more of these categories (NRC, 2000, p. 29). Although students cannot easily participate in data-collection activities during a lecture, they can analyze provided data and communicate their explanations. One strategy for improving students' scientific explanations is to use the Claim, Evidence, Reasoning format (McNeil and Krajcik, 2008). McNeil and Krajcik (2008, p. 123) define a claim as "an assertion or conclusion that addresses the original question or problem about a phenomenon." Students usually do well with this part of their scientific explanations; however, they are less skilled at connecting scientific data (evidence) to their claims. The final component is the reasoning that "links the claim and evidence and shows why the data count as evidence to support the claim" (McNeil and Krajcik, 2008, p. 123-124). This portion is the most difficult for students and, if done well, it shows their true understanding of the topic at hand.

Another easily adopted instructional strategy that helps elicit students' prior knowledge and engage them in inquiry is the Predict, Observe, Explain (POE) learning cycle (Gunstone and White, 1981; White and Gunstone, 1992). In this model, students are first asked to make a prediction about a phenomenon (e.g., what will happen to the $\mathrm{pH}$ of the ocean if atmospheric $\mathrm{CO}_{2}$ is increased?) and share this prediction with their classmates using the think-pair-share strategy. After the sharing, students can test their predictions in a lab setting, through observing a teacher demonstration, or by analyzing provided data. To address the example question above, students could monitor the change in $\mathrm{pH}$ of a sample of ocean water that has a piece of dry ice added to it with either a $\mathrm{pH}$ probe or standard $\mathrm{pH}$ paper. After their "observations," students are to again commit to an explanation of what actually occurred using the claim-evidencereasoning strategy and then again share their findings with their classmates and the teacher. Students may adjust their initial conceptions upon hearing their classmates' ideas. Through the teacher's final discussion on the topic, student conceptions should be clarified.

\section{QUESTIONING SKILLS}

Basic to good questioning is the use of "wait time I" and "wait time II" (Rowe, 1974, 1986). Wait time I is when an instructor asks a question and then waits three to five seconds before calling on a student to allow all students in the class to think about the answer. Wait time II is when the instructor waits three to five seconds before responding to a student's answer. Use of wait time is an easy way to encourage more active student thinking in both the lab and lecture setting.

Robert J. Feller (feller@biol.sc.edu) is Director, Center for Science Education and Professor, Marine and Biological Sciences, University of South Carolina, Columbia, SC, USA. Christine R. Lotter (lotter@mailbox. sc.edu) is Assistant Professor, Secondary Science Education, University of South Carolina, Columbia, SC, USA. 
Students get a bit nervous during both types of wait time because they do not know whether they might get called upon or whether the answer they provided was somehow incorrect or not. Such uncertainty (on their part!) keeps them much more attentive to what is being discussed-no more sleeping in the back row.

Sometimes the same students always raise their hands to answer questions, which leaves many others disengaged. A simple and fair way of encouraging all class members to participate is to set up a near-random way of calling on stu-

dents. This could be done using a computer to randomly select student names or a using a low-technology version in which students' names are written on large popsicle sticks or tongue depressors and are pulled out of a cup by someone in the front row after the teacher asks a question. After the first stick designates a student to answer the question, that student could then pull out another stick for a different student to answer the next question. If you do not replace the sticks after they are drawn, the rest of the students are put on alert-it really works because students seem to enjoy putting pressure on their peers.

The use of divergent-answer questions (those with multiple answers instead of convergent or single answers) is another strategy that instructors can use to increase their students' thinking about and engagement with a topic. Try to steer your questions away from singleanswer vocabulary words or simple recall questions and challenge your students to apply the information from the textbook or your lectures. You can also use questions to provide a real-world context or connection to your lesson. An entire unit of study could be organized around a "driving question" that is a sustained, meaningful question linked to the real world and that holds the unit together (Krajcik et al., 1999). Another feature of a good driving question is that it leads to inquiry investigations that help students find solutions to the problem. For example, RJF most recently (fall semester 2008) used the following driving question in his undergraduate biological oceanography class: "How and in what form does carbon move through the ocean?" Virtually every topic covered during the semester could be related back to this driving question. It was a great coat rack upon which to hang concepts and processes, from vertical migration of zooplankton to sinking fecal pellets. Context can also be provided to students through integrating current events and real-world examples into your lessons.

\section{FORMATIVE ASSESSMENT}

Lastly, you need to determine whether your students really understand anything you have been talking to them about during your lectures or during their laboratory experiences. There are many simple, on-the-spot assessment tools that you can use to determine your students' understanding and adjust your instruction to better teach the concepts. After your lesson, you can hand out index cards to students and have them write down a one-sentence summary of what they learned that day or write down what was still unclear from the day's lesson (Angelo and Cross, 1993; Keeley, 2008). You could also use your Blackboard or other Web-based technology site where students can post their responses to cut down on the load of paperwork that this activity can entail. These responses would then be read and tallied to determine the direction of your next class session.

In large lecture classes, it is often difficult to stimulate effective discussion. If you can designate small (3-5) and diverse (e.g., mixed gender or race) student groups (break up the cliques!) and give them clever names, you can call on groups at random for their input on questions you might pose to all groups as a whole. Forcing such student-tostudent interactions within groups creates engagement for every student and often results in a very noisy classroom. This type of noise and engagement is a good thing.

Quantitative skills can be promoted and practiced by having student groups draw graphs of data or as part of the POE exercise described above. For instance, have each group draw the relationship they would expect between population growth rate and population size in an exponentially increasing population of coastal phytoplankton, a bloom situation. You will be surprised at the lack of graphing skills that usually emerges in such a challenge.

In the laboratory, the more students have to do themselves, the better.

Hands-on activities demand student engagement much more than if the instructor simply demonstrates something to the class. Labs are also a place where the phenomenon first strategy can happen quite easily. Providing an event or experience that all students have before learning the scientific terms and equations associated with a theory can level the playing field in your class and give students a concrete experience to connect to the theory that is introduced later. Perhaps not all of your students have experienced floating in saltwater at the beach or in the Great Salt Lake. 
If you have them perform a laboratory exercise in which they have to float different objects in salt and freshwater, you can then more effectively relate how changes in the density of seawater affect ocean circulation. Many of your students, even at the college level, are still at this concrete operational stage of development and thus need experiential activities to help them understand abstract concepts (Inhelder and Piaget, 1958; Nelson, 1989). Thus, using a learning cycle approach (like the POE model) that places a phenomenon or experience first can help all students learn science (Gunstone and White, 1981).

So, why should STEM faculty change the way they teach? Do their home institutions recognize, value, and reward teaching excellence? Are criteria in place that demand teaching excellence or are the expectations for one's teaching performance simply that the content be accurate? Are learning outcomes part of course syllabi at your institution? Is student assessment fair and effective? These types of questions are integral to the current reform movement in teaching STEM subjects at undergraduate institutions.

We urge you to try several of the strategies outlined above. Do not be discouraged if you are not immediately comfortable with the seeming loss of control or authority that these student-centered teaching methods entail. Believe us when we say that none of the lecture-based faculty with whom we have worked was particularly thrilled by the prospect of moving out of their comfort zone (presenting lectures) until after they had tried several of the strategies a few times. RJF remembers being particularly resistant to trying the phenomenon-first approach because he was convinced that showing students something without first providing context was simply unthinkable! But, by essentially reversing the order in which the phenomenon (in this case, the use of laptops and software to generate dynamic predator-prey cycles with grass, rabbits, and foxes), it was immediately obvious that students got hooked right away and then WANTED to learn more about why their rabbit population died out! Was it that the grass grew too slowly or because there were too many foxes? Or did the invasive species harm the rabbit population? They could not get enough of the exercise and listened more intently than any other previous group of students ( $\mathrm{N} \geq 2500$ over the last 30 years) to his explanation of the Lotka-Volterra equations inherent in generating these cycles. Think how eager your students are to learn about the equations if they have not yet had an opportunity to see them in action-NOT! It was an amazing difference, and RJF will never go back to the context-first approach again-no way (Feller et al., 2008).

\section{THE BOTTOM LINE?}

Try some of these strategies-you might just like the refreshing changes that will magically happen in your classroom.

Engaged students learn better and more than bored students being lectured to. 四

\section{REFERENCES}

Angelo, T.A., and K.P. Cross. 1993. Classroom Assessment Techniques: A Handbook for College Teachers, Second Edition. Jossey-Bass, San Francisco, CA, 448 pp.

Ausubel, D.P. 1960. The use of advance organizers in the learning and retention of meaningful verbal material. Journal of Educational Psychology 51:267-272.

Bransford, J., A. Brown, and R. Cocking, eds. 2000. How People Learn: Brain, Mind, Experience, and School. National Academies Press, Washington, DC, 374 pp.

Feller, R.J. 2007. 110 Misconceptions about the ocean. Oceanography 20(4):170-173.

Feller, R.J., C.R. Lotter, and J.E. Singer. 2008. An awakening (Part II): How you can help science education. Oceanography 21 (2):68-71.

Gunstone, R.F., and R.T. White. 1981. Understanding of Gravity. Science Education 65(3):291-299.

Hammer, D. 1995. Student inquiry in a physics class discussion. Cognition and Instruction 13(3):401-430.

Handelsman, J., D. Ebert-May, R. Beichner, P. Bruns, A. Chang, R. DeHaan, J. Gentile, S. Lauffer, J. Stewart, S.M. Tilghman, and W.B. Wood. 2004. Policy Forum: Education: Scientific teaching. Science 304:521-522, doi:10.1126/science.1096022.

Inhelder, B., and J. Piaget. 1958. The Growth of Logical Thinking From Childhood to Adolescence. Basic Books, New York, 356 pp.

Kagan, S. 1994. Cooperative Learning. Kagan Cooperative Learning, San Clemente, CA.

Keeley, P. 2008. Science Formative Assessment: 75 Practical Strategies for Linking Assessment, Instruction, and Learning. National Science Teachers Association Press and Corwin Press, Washington, DC, 233 pp.

Krajcik, J.S., C. Czerniak, and C. Berger. 1999. Teaching Children Science: A Project-Based Approach. McGraw-Hill College, Boston, MA, 356 pp.

Lortie, D. 1975. Schoolteacher: A Sociological Study. University of Chicago Press, Chicago, IL, 284 pp.

Mazur, E. 2008. Farewell, Lecture? Science 323:50-51.

McNeil, K.L., and J.S. Krajcik. 2008. Inquiry and scientific explanations: Helping students use evidence and reasoning. Chapter in J.A. Luft, R.L. Bell, and J. Gess-Newsome, eds, Science as Inquiry in the Secondary Setting, NSTA Press, Arlington, VA.

Nelson, C. 1989. Skewered on the unicorn's horn: The illusion of tragic tradeoff between content and critical thinking in the teaching of science. Pp. 17-27 in L.W. Crow, ed., Enhancing Critical Thinking in the Sciences, Society of College Science Teachers, Washington, DC.

Gunstone, R.F., and R.T. White. 1981. Understanding of Gravity. Science Education 65(3):291-299.

National Research Council (NRC). 2000. Inquiry and the National Science Education Standards: A Guide for Teaching and Learning. National Academies Press, Washington, DC, 202 pp.

Posner, G.J., Strike, K.A., Hewson, P.W., and W.A. Gertzog. 1982. Accommodation of a scientific conception: Toward a theory of conceptual change. Science Education 66(2):211-227.

Rowe, M.B. 1974. Wait-time and rewards as instructional variables, their influence on language, logic, and fate control: Part one-wait-time. Journal of Research in Science Teaching 11(2):81-94.

Rowe, M.B. 1986. Wait time: Slowing down may be a way of speeding up! Journal of Teacher Education 37(1):43-50.

Smith, M.K., W.B. Wood, W.K. Adams, C. Wieman, J.K. Knight, N. Guild, and T.T. Su. 2008. Why peer discussion improves student performance on inclass concept questions. Science 323:122-124.

White, R.T., and R.F. Gunstone. 1992. Probing Understanding. Routledge, Great Britain, 196 pp. 